\title{
Genetic Divergence and Relationship Analysis among the Okra (Abelmoschus esculentus L. Moench.) Cultivars by Morphological Traits
}

\author{
Vinay Verma ${ }^{1}$, Bijendra Singh ${ }^{1}$, M.K. Singh ${ }^{1}$ and S.K. Singh ${ }^{2}$ \\ ${ }^{1}$ Department of Horticulture, ${ }^{2}$ Department of Genetics and Plant Breeding \\ SVPUAT, Meerut-250110, UP, India \\ *Corresponding author
}

\begin{abstract}
A B S T R A C T
Genetic diversity is the first and important parameter in crop improvement programme. In the present investigation fifty okra genotypes were assessed to know the nature and

Keywords

Genetic divergence, Morphological traits, Okra

Article Info

Accepted: 08 July 2018 Available Online: 10 August 2018 magnitude of genetic divergence by using Mahalanobis $\mathrm{D}^{2}$ statistics. The genotypes were grouped into seven clusters. Among seven clusters, Cluster VII was largest with 11 genotypes followed by, cluster IV having 10 genotypes. The intra-cluster was maximum in cluster IV $\left(D^{2}=2.54\right)$ reveals maximum genetic diversity followed by, cluster VI $\left(D^{2}=\right.$ 2.38) and cluster VII $\left(\mathrm{D}^{2}=2.36\right)$. The maximum inter cluster distance was observed between cluster II and cluster $\mathrm{V}\left(\mathrm{D}^{2}=5.31\right)$ followed by, cluster II and VI $\left(\mathrm{D}^{2}=4.62\right)$ and minimum cluster distance was observed between VI and VII (2.32). The length of first fruiting node, length of internode, fruit shape and number of fruits per plant is the qualitative traits in okra and it is considered that the genotypes showed highest mean value among the clusters should be given more weightage. The different clusters have higher mean values for different traits and the genotypes consisting in cluster II. V and VII have higher mean value for these traits deserve to be considered as potent parents for further improvement programme.
\end{abstract}

\section{Introduction}

Okra [Abelmoschus esculentus L. (Moench)] is an economically important vegetable crop grown in tropical and sub-tropical parts of the world. This crop is suitable for cultivation as a garden crop as well as on large commercial farms. It is quite popular in India because of easy cultivation, dependable yield and adaptability to varying moisture conditions. Even within India, different names have been given in different regional languages (Chauhan, 1972). Okra is cultivated for its fibrous fruits or pods containing round, white seeds. Its ripe seeds are roasted, ground and used as a substitute for coffee in some countries. Mature fruits and stems containing crude fibre are used in the paper industry. Extracts from the seeds of the okra is viewed as alternative source for edible oil. The oil content of the seed is quite high at about $40 \%$. Okra provides an important source of vitamins, calcium, potassium and other mineral matters which are often lacking in the diet of developing countries (IBPGR, 1990). For planning and execution of successful crop 
breeding programme, information on evaluation of available okra germplasm for selecting donor parents in hybridization programme and understanding character association are very important and useful aspects.

\section{Material and Methods}

The experimental material of the present investigation comprising fifty genotypes of okra were evaluated in a randomized block design with three replications during kharif 2016-17 at Horticulture Research Centre, Sardar Vallabhbhai Patel University of Agriculture and Technology, Meerut, U.P. Observations were recorded on five competitive plants for days to flowering, plant height $(\mathrm{cm})$, number of branches per plant, length of first fruiting node $(\mathrm{cm})$, number of first fruiting node, Length of internode $(\mathrm{cm})$, length of fruit $(\mathrm{cm})$, width of fruit $(\mathrm{cm})$, number of fruits per plant, yield per plant (g).The mean value of genotypes in each replication was used for statistical analysis. The data were analysed for a randomized block design to test the significance of differences between the genotypes for various characters. The steps involved in the analysis of the randomized block design were as described by Panse and Sukhatme (1969).The test of significance was worked out by referring to the standard ' $F$ ' table suggested by Snedecor (1967). The genetic diversity among fifty okra accessions was assessed by using $\mathrm{D}^{2}$ Mahalanobis statistics (Mahalanobis, 1936). The grouping of accessions was done using Tocher's method, as described by Rao (1952). The genotypes were arranged in the order of their relative distance from each other. The values were arranged in ascending order of magnitude in each column.

\section{Results and Discussion}

The data collected on all ten parameters under study was subjected to the standard statistical analysis. The analysis of variance was done for all the characters to test the significance among the genotypes under study (Table 1). The sum squares due to genotypes were further partitioned in to Replication, Genotypes and Error or highly significance variance was observed for all ten characters under study. This analysis revealed that significant differences exist among the genotypes in the present investigation for all the ten characters studied viz., days to flowering, plant height, number of branches per plant, length of first fruiting node, number of first fruiting node, length of internode, length of fruit, width of fruit, number of fruits per plant, and yield per plant.

After computing $\mathrm{D}^{2}$ value for all the possible pairs fifty genotypes were grouped into seven clusters using Toucher's method (Rao 1952) which indicated large genetic diversity. On the basis of Mahalanobis $\mathrm{D}^{2}$ values, all the 50 genotypes were grouped into 7 clusters. The distribution patterns of okra genotypes into 7 clusters are shown in Table 2. Cluster VII contained maximum number of genotypes (11) comprising IC 90243, SEL. 10, EC 3016556, VRO - 5, EC 329357, HRB - 55, IC 90225, IC 282232, IC 90196, IC 90244, IC 33345; followed by, cluster IV containing 10 genotypes viz., IC 42472, IC 27881 A, IC 18541 A, IC 18536, SB - 8, SB - 6, Punjab Padmini, IC 18544, 133-10-1,2,3,4, IC 90096. While, cluster VI comprising (9) genotypes namely IC 34124, IC 90134, IC 33963, IC 90107, IC 5407, IC 45831, IC 34190 C, IC 42470, IC 90082. Cluster III containing (7) genotypes viz., IC 42456 A, IC 90098, IC 42423 B, IC 27874, IC 90199, IC 90242, IC 42451. Cluster I comprising of (6) genotypes namely IC 90201, IC 22283, IC 34190, IC 39143, IC 12934, IC 90078. Whereas, cluster V comprised (4) genotypes viz., IC 39137 A, VRO - 6, Parbhani Kranti, IC 45831. Cluster II having (3) genotype viz., IC 42464, DOV91-4, 440-10-1. The grouping pattern of the genotypes suggested no parallelisms between 
genetic divergence and geographical distribution of genotypes. These results are in conformity with the findings of Pradip et al., (2010), Garg et al., (2011), Umrao et al., (2014).

Intra and inter cluster $\mathrm{D}^{2}$ values and corresponding genetic distance are presented in Table 3. The intra-cluster was maximum in cluster IV $\left(D^{2}=2.54\right)$ reveals maximum genetic diversity followed by, cluster VI $\left(D^{2}\right.$ $=2.38)$ and cluster VII $\left(D^{2}=2.36\right)$. Hence, selection within this cluster may be exercised based on highest area of desirable traits. The choice of parents is of paramount importance in breeding programmes where crosses are to be assessed. The inter cluster distance $\left(D^{2}\right)$ is main criteria for selection of genotypes. The maximum inter-cluster values $\left(\mathrm{D}^{2}=5.31\right)$ was observed between cluster II and cluster V exhibited maximum divergence followed by, cluster II and VI $\left(\mathrm{D}^{2}=4.62\right)$ while, the lowest $\left(D^{2}=2.32\right)$ values was observed between cluster VI and cluster VII indicating close relationship and similarity for most traits of all genotypes. These results are in conformity with the findings of Prakash et al., (2011), Sanwal et al., (2012), Koundinya et al., (2013).

Cluster means for 10 characters are present in
Table 4. The existence of diversity among the genotypes was also assessed by the considerable amount of variation in cluster means for different characters. The cluster-II recorded highest cluster mean value for Days to flowering, length of internode, width of fruit. Cluster V recorded highest cluster mean value for number of fruits per plant and yield per plant. Days to flowering, length of fruit, width of fruit, and number of fruits per plant are the qualitative traits in okra and it is considered that the genotypes showed highest mean value among the clusters should be given more weightage. These results are close conformity with the findings of Garg et al., (2011), Pradip et al., (2010) and Bendale et al., (2003).

The percentage contribution of different characters towards genetic divergence is presented in Table 5. Ranking character wise $\mathrm{D}^{2}$ values which contributed towards the divergence. Days taken to flowering contributing maximum (15.99 \%) towards total divergence and this was followed by plant height $(14.78 \%)$, number of branches per plant $(12.82 \%)$, length of first fruiting node $(11.73 \%)$, length of fruit $(9.44 \%)$, number of first fruiting node $(8.17 \%)$, length of internode $(8.12 \%)$, width of fruit $(8.04 \%)$, yield per plant $(5.67 \%)$ and number of fruits per plant $(5.25 \%)$.

Table.1 Analysis of variance (ANOVA) mean sum square for ten characters of okra

\begin{tabular}{|c|c|c|c|c|c|c|c|c|c|c|c|}
\hline $\begin{array}{l}\text { Source of } \\
\text { Variation }\end{array}$ & $\mathrm{DF}$ & $\begin{array}{l}\text { Days to } \\
50 \% \\
\text { flowering }\end{array}$ & $\begin{array}{c}\text { Plant } \\
\text { height } \\
(\mathrm{cm})\end{array}$ & $\begin{array}{l}\text { Number } \\
\text { of } \\
\text { branches } \\
\text { per plant }\end{array}$ & $\begin{array}{l}\text { Length of } \\
\text { first fruiting } \\
\text { node }(\mathrm{cm})\end{array}$ & $\begin{array}{c}\text { Number } \\
\text { of first } \\
\text { fruiting } \\
\text { node }\end{array}$ & $\begin{array}{l}\text { Length of } \\
\text { internode } \\
\quad(\mathrm{cm})\end{array}$ & $\begin{array}{l}\text { Length } \\
\text { of fruit } \\
\text { (cm) }\end{array}$ & $\begin{array}{l}\text { Width } \\
\text { of } \\
\text { fruit } \\
(\mathrm{cm})\end{array}$ & $\begin{array}{l}\text { Number } \\
\text { of fruits } \\
\text { per plant }\end{array}$ & $\begin{array}{l}\text { Yield } \\
\text { per plant } \\
\quad(g)\end{array}$ \\
\hline Range & & $\begin{array}{l}37.87- \\
47.53\end{array}$ & $\begin{array}{c}95.32- \\
125.81\end{array}$ & $\begin{array}{c}1.57- \\
4.40\end{array}$ & $9.56-17.55$ & $\begin{array}{c}4.33- \\
7.53\end{array}$ & $\begin{array}{c}4.07- \\
7.33\end{array}$ & $\begin{array}{c}10.18- \\
15.83\end{array}$ & $\begin{array}{c}1.29- \\
2.34\end{array}$ & $\begin{array}{l}9.33- \\
16.45\end{array}$ & $\begin{array}{c}95.97- \\
187.40\end{array}$ \\
\hline Replication & 2 & 5.44 & 18.54 & 0.246 & 3.05 & 0.22 & 0.65 & 1.60 & 0.048 & 1.28 & 22.77 \\
\hline Treatment & 49 & $18.78^{* *}$ & $152.39 * *$ & $1.688 * *$ & $11.53 * *$ & $1.86^{* *}$ & $2.06 * *$ & $4.76^{* *}$ & $0.207 * *$ & $6.31 * *$ & $2596.81 * *$ \\
\hline Error & 98 & 1.99 & 14.42 & 0.172 & 0.23 & 0.03 & 0.04 & 0.18 & 0.003 & 0.12 & 20.12 \\
\hline
\end{tabular}


Table.2 Clustering pattern of 50 genotypes of okra on the basis of Mahalanobis $\mathrm{D}^{2}$ statistics

\begin{tabular}{|c|c|c|}
\hline Clusters & $\begin{array}{c}\text { No of } \\
\text { genotypes }\end{array}$ & Genotype name \\
\hline $\mathbf{I}$ & 6 & IC 90201, IC 22283, IC 34190, IC 39143, IC 12934, IC 90078 \\
\hline II & 3 & IC 42464, DOV - 91- 4, 440 - $10-1$ \\
\hline III & 7 & $\begin{array}{l}\text { IC } 42456 \text { A, IC 90098, IC } 42423 \text { B, IC 27874, IC 90199, } \\
\text { IC 90242, IC } 42451\end{array}$ \\
\hline IV & 10 & $\begin{array}{l}\text { IC 42472, IC 27881 A, IC } 18541 \text { A, IC 18536, SB - 8, SB - 6, Punjab Padmini, IC } \\
\text { 18544, 133-10-1,2,3,4, IC } 90096\end{array}$ \\
\hline $\mathbf{V}$ & 4 & IC 39137 A, VRO - 6, ParbhaniKranti, IC 45831 \\
\hline VI & 9 & $\begin{array}{l}\text { IC 34124, IC 90134, IC 33963, IC 90107, IC 5407, IC 45831, } \\
\text { IC } 34190 \mathrm{C} \text {, IC 42470, IC } 90082\end{array}$ \\
\hline VII & 11 & $\begin{array}{l}\text { IC 90243, SEL. 10, EC 3016556, VRO - 5, EC 329357, } \\
\text { HRB - 55, IC 90225, IC 282232, IC 90196, IC 90244, IC } 33345\end{array}$ \\
\hline
\end{tabular}

Table.3 Average intra and inter cluster $\left(\mathrm{D}^{2}\right.$ value $)$ distance in fifty genotypes of okra

\begin{tabular}{|c|c|c|c|c|c|c|c|}
\hline Clusters & I & II & III & IV & V & VI & VII \\
\hline I & 2.24 & & & & & & \\
\hline II & 3.65 & 2.11 & & & & & \\
\hline III & 2.80 & 2.81 & 2.09 & & & & \\
\hline IV & 2.68 & 3.40 & 3.47 & 2.54 & & & \\
\hline $\mathbf{V}$ & 3.95 & 5.31 & 4.16 & 3.39 & 2.28 & & \\
\hline VI & 3.43 & 4.62 & 3.61 & 3.08 & 3.17 & 2.38 & \\
\hline VII & 3.27 & 3.71 & 2.58 & 2.88 & 3.56 & 2.32 & 2.36 \\
\hline
\end{tabular}


Table.4 Cluster mean values for ten characters in okra

\begin{tabular}{|c|c|c|c|c|c|c|c|c|c|c|}
\hline Clusters & $\begin{array}{c}\text { Days to } \\
50 \% \\
\text { flowering }\end{array}$ & $\begin{array}{l}\text { Plant height } \\
(\mathrm{cm})\end{array}$ & $\begin{array}{l}\text { Number of } \\
\text { branches } \\
\text { per plant }\end{array}$ & $\begin{array}{l}\text { Length of } \\
\text { first } \\
\text { fruiting } \\
\text { node }(\mathrm{cm})\end{array}$ & $\begin{array}{c}\text { Number } \\
\text { of first } \\
\text { fruiting } \\
\text { node }\end{array}$ & $\begin{array}{l}\text { Length of } \\
\text { internode } \\
\quad(\mathrm{cm})\end{array}$ & $\begin{array}{l}\text { Length of } \\
\text { fruit }(\mathrm{cm})\end{array}$ & $\begin{array}{l}\text { Width of } \\
\text { fruit }(\mathrm{cm})\end{array}$ & $\begin{array}{l}\text { Number } \\
\text { of fruits } \\
\text { per plant }\end{array}$ & $\begin{array}{l}\text { Yield per } \\
\text { plant }(\mathrm{g})\end{array}$ \\
\hline II & 45.78 & 100.53 & 2.05 & 15.18 & 5.29 & 6.61 & 15.02 & 1.83 & 10.48 & 102.42 \\
\hline III & 40.10 & 107.28 & 2.11 & 14.98 & 5.29 & 6.45 & 15.40 & 1.58 & 11.30 & 115.57 \\
\hline IV & 45.16 & 104.08 & 2.15 & 15.02 & 6.07 & 5.36 & 13.01 & 1.53 & 12.44 & 139.94 \\
\hline VI & 42.18 & 115.22 & 3.05 & 15.00 & 5.54 & 6.59 & 12.70 & 1.68 & 12.39 & 168.12 \\
\hline VII & 41.36 & 111.98 & 3.25 & 15.81 & 5.69 & 5.74 & 14.01 & 1.81 & 11.63 & 124.18 \\
\hline
\end{tabular}

Table.5 Contribution of different characters in creating diversity in okra based on Mahalanobis's D² analysis

\begin{tabular}{|c|l|c|}
\hline S.L. & Characters & \% contribution \\
\hline $\mathbf{1}$ & Days to 50\% flowering & 15.99 \\
\hline $\mathbf{2}$ & Plant height $(\mathrm{cm})$ & 14.78 \\
\hline $\mathbf{3}$ & Number of branches per plant & 12.82 \\
\hline $\mathbf{4}$ & Length of first fruiting node $(\mathrm{cm})$ & 11.73 \\
\hline $\mathbf{5}$ & Number of first fruiting node & 8.17 \\
\hline $\mathbf{6}$ & Length of internode $(\mathrm{cm})$ & 8.12 \\
\hline $\mathbf{7}$ & Length of fruit $(\mathrm{cm})$ & 9.44 \\
\hline $\mathbf{8}$ & Width of fruit $(\mathrm{cm})$ & 8.04 \\
\hline $\mathbf{9}$ & Number of fruits per plant & 5.25 \\
\hline $\mathbf{1 0}$ & Yield per plant $(\mathrm{g})$ & 5.67 \\
\hline
\end{tabular}


The kind of genetic diversity found among the genotypes belonging to same geographical region might be due to differences in adaptation, selection criteria, selection pressure and environmental conditions. Similar observations have been recorded by Umrao et al., (2014), Prakash et al., (2011), Nwangburuka et al., (2011) and Dhaduk et al., (2004).

In conclusion, the analysis of variance was done for all the characters to test the significance among the genotypes under study. This analysis revealed that significant differences exist among all the genotypes. The present investigations conclude that five genotypes namely IC-45831, Parbhanikranti, VRO-6, IC39137A and Punjab pudmini resulted in higher yield and also performed better for other horticultural traits viz. plant height, number of branches per plant, length of first fruiting node and length of fruit. The genotypes having varied performances were grouped into 7 clusters following Tocher's method on the basis of $\mathrm{D}^{2}$ values for clustering the population into clusters and sub-clusters. Thus this grouping of genotypes has great relevance to the future breeding programme and the genotypes included in diverse clusters are likely to produce potential hybrids. Once the desirable hybrids are obtained they could be maintained and multiplied through asexual reproduction for commercial use.

\section{References}

Bendale, V.W., Kadom, S.R., Bhave, S.G., Mehta, J.J. and Pethe, U.B. (2003). Genetic Variability and correlation studies in Okra. Orissa J. Hort., 31(2): $1-4$

Chauhan, D.V.S. (1972).Vegetable Production in India $\left(3^{\text {rd }}\right.$ edn. $)$ Ram Prasand and Sons, Agra.
Dhaduk, L.K., Mehta, D.R. and Patel, K.D. (2004). Genetic diversity in okra. Orissa J. Hort., 32(1): 70-72.

Garg, R., Pathak, M. and Bal, S.S. (2011). A study on genetic diversity among okra varieties. Crop Improvement., 38(1): 48-52.

Koundinya, K.R., Chaudhary, R. and Khatik, C.L. (2013). Genetic variability and divergence in okra [Abelmoschus esculentus(L.) Moench]. Indian Journal of Agriculture Science. 83(6): 685-688.

Mahalanobis, P. C. (1936). On the generalized distance in statistics. Proc. Natl. Acad. Sci. India.2(1): 49-55

Nwangburuka, C. C. Denton, O. A. Kehinde, O. B. Ojo, D. K. Popoola, A. R. (2011). Morphological classification of diversity in cultivated okra [Abelmoschus esculentus (L.) Moench] using principal component analysis (PCA) and single linkage cluster analysis (SLCA). African J. Biotechnology., 10(54): 11165-11172.

Panse, N.G. and P.V. Sukhatme. (1967). Statistical methods for agriculture workers. ICAR Publ. 347.

Pradip, K., Akotkar, D.K. De and Pal, A.K. (2010). Genetic variability and Diversity in okra [Abelmoschus esculentus (L.) Moench]. Electronic Journal of Plant Breeding.1(4): 393398.

Prakash, K., Pitchaimuthu, M. and Ravishankar, K.V. (2011). Assessment of genetic relatedness among okra genotypes [Abelmoschus esculentus (L.) Moench] using RAPD markers. Electronic Journal of Plant Breeding 2(1):80-86

Rao, C. R. (1952). Advance Statistical methods in biometrical Research Edition I. John Wiley and Sons. New York 
Sanwal, S.K., Singh, B. and Verma, S.S. (2012). Genetic divergence and its implication in breeding of desired plant type in okra [Abelmoschus esculentus (L.) Moench]. Indian Journal of Agriculture Science.82(3): 264-266.

Snedecor, G.W. (1967) Statistical methods. The Lowa State University Press, IOWA, U.S.A.
Umrao, V., Sharma, S.K., Rajeev Kumar, Vijai Kumar and Alka Sharma. (2014). Genetic variability and divergence analysis in okra [Abelmoschus esculentus $(\mathrm{L}$.) Moench]. Hort Flora Research Spectrum. 3(2): 127-132.

\section{How to cite this article:}

Vinay Verma, Bijendra Singh, M.K. Singh and Singh, S.K. 2018. Genetic Divergence and Relationship Analysis among the Okra (Abelmoschus esculentus L. Moench.) Cultivars by Morphological Traits. Int.J.Curr.Microbiol.App.Sci. 7(08): 1236-1242.

doi: https://doi.org/10.20546/ijcmas.2018.708.139 